\title{
Proceedings of the Fifty-Ninth Anniversary Meeting
}

\section{B. Burgess Captain, Secretary}

To cite this article: B. Burgess Captain, Secretary (1889) Proceedings of the Fifty-Ninth Anniversary Meeting, Royal United Services Institution. Journal, 33:S1, i-xxvii, DOI: 10.1080/03071848909418402

To link to this article: http://dx.doi.org/10.1080/03071848909418402

\section{册 Published online: 25 Sep 2009.}

Submit your article to this journal $\sqsubset x$

Џll Article views: 3

Q View related articles $匚$ 


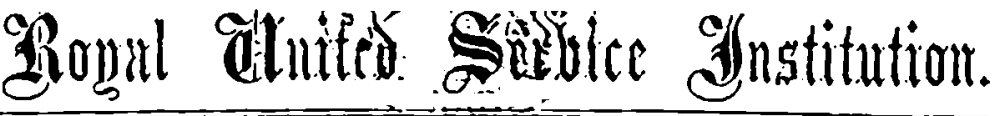
Vor. XXXIII. 1889-90. APpENDIX.

PHOCEEDINGS OF THE FIF'TY-NINIHI ANNIVERSARY MEETING.

line Firtr-Nixti Axivelisime Mefisiag of the Members was held in the Thentre of the Institution, on Snturday, March 1st, 1890, 'The light IIon. Lond Grongr: Il.sum.sos, M.P., First Lord of the Aduiralty; in ilho Chair.

I. The Secretary read the notico convening the Mecting.

II. 'Tho lifty-Ninth Aunual Report was reat as follow's:-

1. The Council have the pleasure of subuitting their Report for the year 1889.

\section{Mr.Misers.}

2. Thirty-five Life Members and One hundred aud Thirteen Anmual Subscribers, making a total of One hundred and Forty-eight m.N Nembers, joined the: Institution during the pasi yenr. Tho lo is ly dentil amounted to Lighty-four, and Sisty-soren Licnocrs withlre'utheir names.

'lle names of Twenty-cight Anmual Suischibers, whose subecriptions were in arrears fur two jears, have, in accordance with Section $V$, par: 6, of the Bye-laws, been struck off tho list of Members.

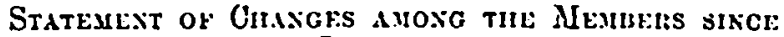
lst Jaxcali, J8S9.

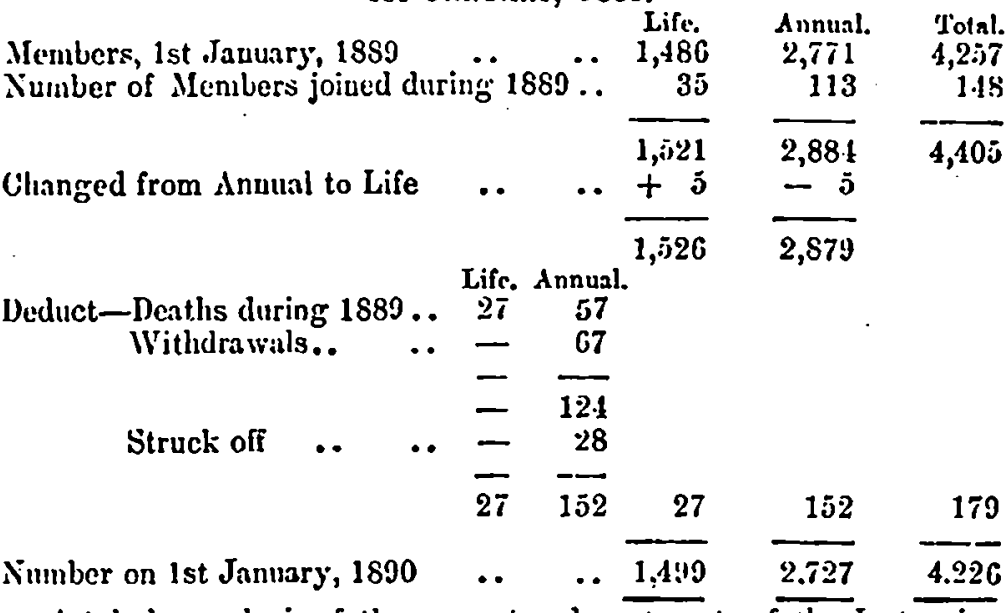

A tabular analysis of the present and past state of tho Justuntion is given in Appendix $\Lambda$.

for detail of Anumal Subscribers, seo Appendix 13. 
ii PrOCEEDINGS OF THF FIFTY-XINTI ANXIVERSARY JEETING.

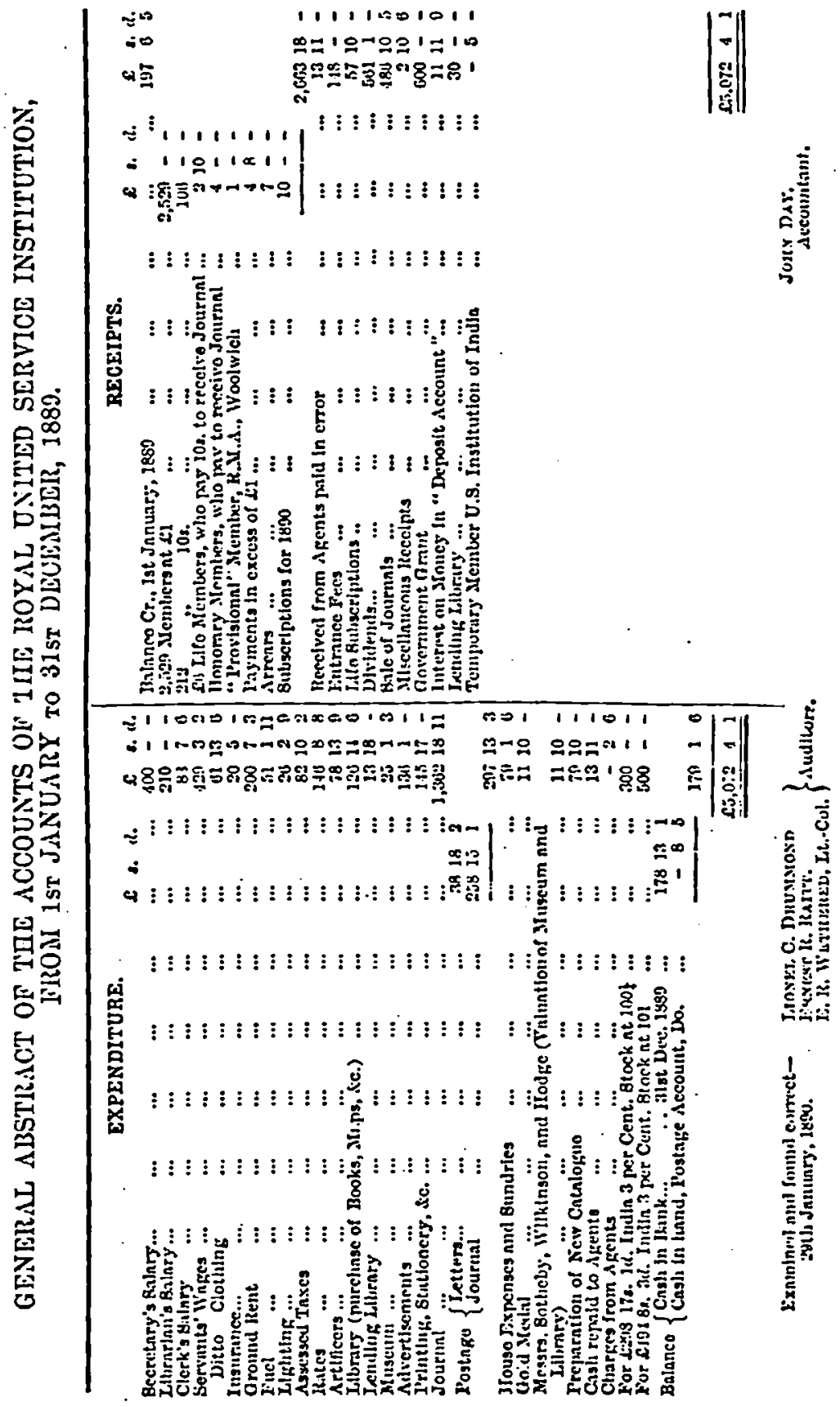


PROCEEDINGS OF THE FIETT-XINTIT ANXIYERS.IKY JERT:TING,

iii

Fixdxce.

3. An Alistract of tho Accounts, duly audited, is given on tho opposite page.

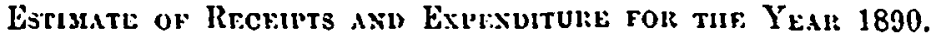

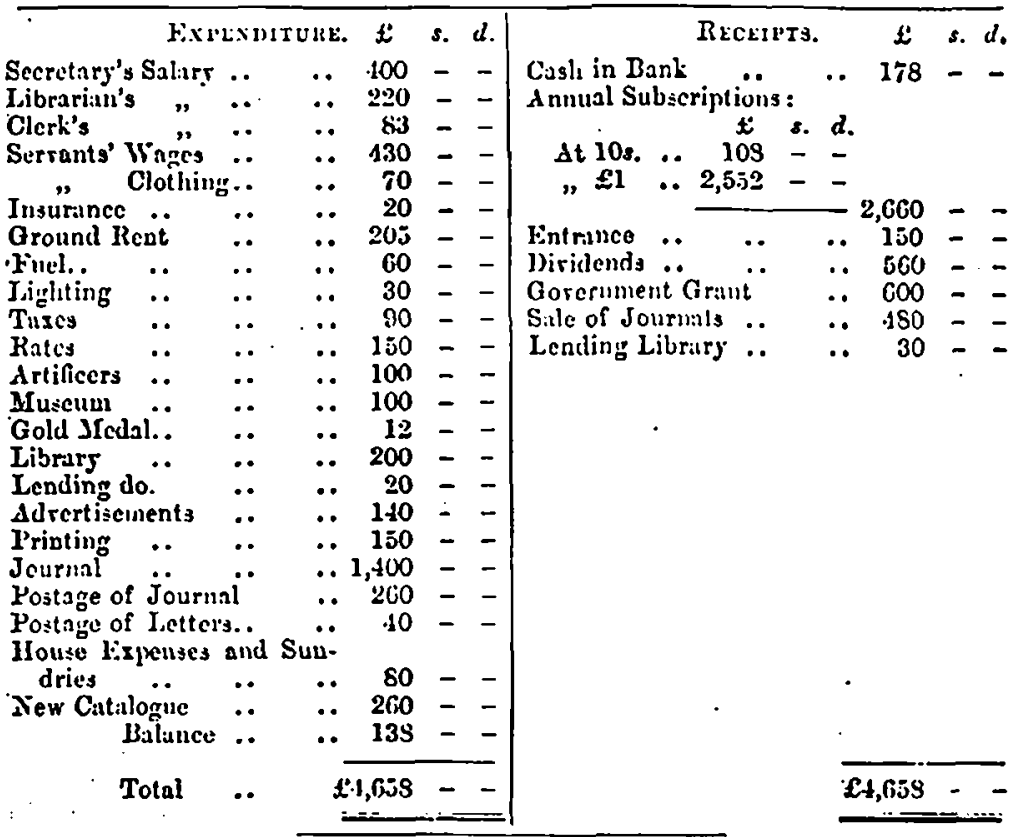

Ijtfe Sunscriptiona anil Capital account.

4. Ijfe Subscriptions to the amount of $£+100$ have been invested in India 3 per Cent. Stock. III addition, $\$ 400$ of. "Incolme" hare also bcen invested in India 3 per Cent. Stock. 'These sums represent f793 js. 4/l. of Stoch. The invested property of the Institution is thus raised to $£ \geq 0,49 S$ 12s. 8d. (sco Appendix C.), of which $\mathcal{L} 15,891$ 10s. 2 l. of stock, is the accumulation of Life Subscriptious, anil $f\rfloor, 60.12 s$. Gol. of stock, tho anount placed to the credit of tho General Fund.

Tinf Futun: Locdlity of the Isstitutios.

5. The Council regret that they are not in a position to report a definite arrangement respecting the future locality of the Institution. Ou the Cth January, 1888, and arain on the 12th A pril, 1889, the Council appealed to the 'lreasury to provide new premises in lieu of thnse now in occupation, and a Ilemorial (see Appendix D) was presented to tho Chancellor of the Exchequer on the 20th June. 'To this the Chairman received on the 3rit September last, a provisional reply, in which at promise was given that the subject should receiro the early attention of the Chancellor of the Fxchenuer on his returu to London, and the question is at the present tine under his consideration. 


\section{l'Arkis.}

6. Papers on the following subjerts were real and discussed during the year, and havo aplieared in the Journal, viz.:-

Captals Frexcrs G. Stuxe, r.s.c., R.A. (Institution P'rize Jredallist, 1883), on - "Quict-firing Guns for Fortrcss Jefence."

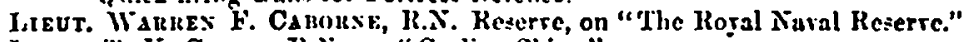

IAfUr. 'T. Y. Anfer, R.X., on "Cualing Sllipe."

M.asor.Grxena I. C. If. Owex, late R.A., on "The Value of Artillery in the Field."

Jons Dosald:ox, MI.I.C.F. (Messts. J. I. Thornycroft d. Co.), on "Ihle more Recent Improrements in 'Thomyerofe 'Torpedo Boat s."

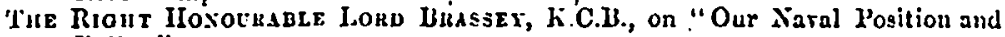
I'olicy.".

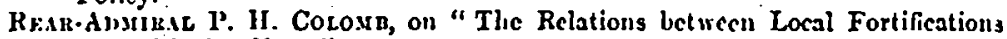
and " Moring Nirr."

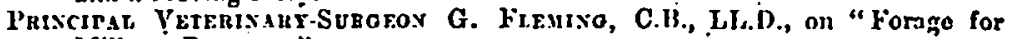
Jilitars Purposes."

Vetrasiakt-Sukgex F. E. Brxiseit, on "The Fmpluyment of Dogy for Mlilitary Purposce."

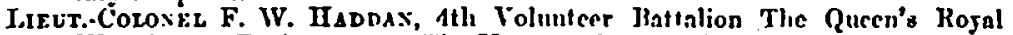
West Surreg Regiment, on "The Howe l)efence Bill as nffecting the Volun. tcers."

Scrocos-Majolz J. L. Notren, II D. (Professor of Mrgicne, Arms Medical Sel:ool, Fetler), on "The Soldicr's Food, with reference to Health and Efficiencs for Servico."

W. II. Ds.rnivo, F.C.S., F.I.C. (Chicf dssistant Chemist, Winr Jepartment), on "Recent Inventions in Gunpowiler and of lier Fixplosires."

Lestrexast W. C. Cretchles, R.X. Rescrre, on "The Unprotected State of Britisl, Coumerce at Sca."

Cotosel I.ossible IIses (retired R.E.), on "The reçent Changes in the Drill of the Gernan Armig."

Mison G. K. W $\triangle$ LEer, K.E. (the lutc), on "Fortificationa and Flcets."

Cartals WV. J. Robertsos, R.H.A., on "Horec Artillery" Part II.

Liettrinati-Corosel R. Elis, h.p. (late East lancashite Rigiment), on "Luncers and Lances."

Cososfr. A. B. Tulzocr, C.B., li.p., (late the Welsh lieginent), on "Battle 'Training of Reginental Ovicers."

Captais Gerated II. V. Noet, R.N. (Gold Jicdalist, R.U.S.I.), on "The Training of the Fisecutire Branch of the Narr."

Derotr-Srrofox GesRraz W. G. Dos, Ji.D., on "Recruits and Recruiting."

LieOtexast-Coloser ji. L. Watfonv, h.p., R.d., on "The Tuetics of Coast. Defence."

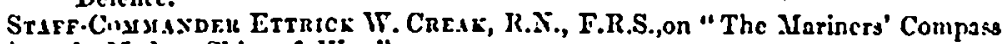
in Jodern Ships of War."

Phtscipal Vetehisart-Siroeos A. Flentrio, C.B., ILLD., F.R.C.V.S., on "Forago for Jllitary Purpusca." Pait II.

Mr. J.Astrs Rigo, C.E., on "The Itechanical Coaling of Steamers."

c. F. H1. Culdorrces-II tcers, on "The Naral Volunteers."

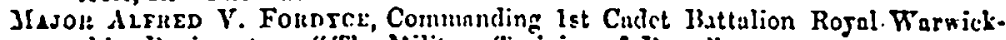
glie Kegiwent, on "The Jtilitnry Training of Boys."

The thanks of the Institution are due to the authors for the valuable profesisional information thus afforded.

The theatre was lent to the Tactical Society for tron Lectures; to the Metropolitan Volunteer Serjeants' 'lactical Association for ninu Iectures; and on thirteen other ocinsions to Societies and Associations connected with the Services, for their meetiugs. 


\section{TIE Joursa.}

7. The sale of the Jourual produced $f-186$ as compared with $\mathrm{fizj}^{3}$ in the previous year.

\section{Jabliatis.}

8. The I,ibrary now contains 29,046 volumes, of which four hundred and eighty-one have been added since the last Repmit; of these, cighty-two have been purchased, two hundred and sixfy-five preseuted, and the remainder are bound periodicals, $\delta . c$

The new catalogue is mearly completed, and the Council hope that it will be on sale to Il embers at an early date.

Donations of books and maps have been received from the Governments of Austria, Brazil, Demmark, France, liermany, Italy, ihu: Nethertands, linssia, Sprain, Swellen, Switzerland; and tho Uniterl States.

'The thanks of the Council hare been convejed to the several Governments for theso donations.

The Institution is indeloted to the Jords Commissioners of the: Admiralty, to the Secretaries of State for IVar, and for India, for copics of various works issued by their loepartuents, and to the: Sipeaker of the House of Commons for Parliameutary Papris.

The exchange of Journats with Foreign Governments and witl many Scientific: Societics, in this and other countries, has been conttinued.

A list of the alditions to the Jibrary and to the Museum will tre published in tho "Proccedingrs" of this day'y mecting, and in the Appendix to Vol. XXXIII. of the Jourmal.

I'he I,euding I ibrary (sec Appendix li), available for Members in the United Kingdom, which was opened on the 1st Norember, $18 \mathrm{si}$. has proved a success, not only financially, but also in increasing the usefulness of the lnstitution, 137 Subscribers having availed themselves of it since its formation.

\section{Professionil Informition.}

9. When enquiries ou Naval and Military professional subject: are received from llembers, endeavours are marle either to furuish the information sought for, or to point out where it can be oblained.

\section{MIuseuy.}

10. The Council take this opport unity of thanking Messs. Sir Willi:um Arnstrong, Mitchell \& Co.; tho Naral Coustruction and Armiunint Co.; Messrs. Robert Napier $\mathcal{E}$ Sons; Messrs. Ilonald Currie of (Jo.; the 'Tlames Ironworks and Ship-Building Co. for their valuable assistame' towards forming a I.oan Exhibition of Models of Ships. Such :u Exhibition, if generally assisted by those Ship-building firms who lave 
received orders from H.M.'s Government, would prove of great value and interest to tho Mlembers (and also to the public who visit the Institution), and would, to a great extent, obriato the purchaso of expensive models, which occupy much space, and which, after a tinic, bucome out of dite.

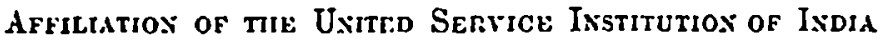 witil the Royal UNithid Service Isstitutios.}

11. The Council recommend that the following proposals for affiliation of the Unitcd Service Institution of India with this Institution, which have been on trial for two years, slonld now becone. permaneut, and be embodied in the hye-laws of this Institution.

\section{Proposals for the Afiliation of the Uniled Serrice Institution of India with the Royal United Sertice Institution.}

d. Proposcd tliat-

1. JIembers of the United Serrice Institution of India procceding to the United Iringlou on two or three montlis" "l'rivilege" Isare, or

Temporary Members on "Pririlege" leave, ös. for sir montlis without the Journil. un gix montlus' Ieste, shall be permitted as "Temporarg Blcinbers" to attend the lectures and to use the Reiding Roow, \&c., of the Rosal United Serrice Institution (but not reccire the Journal) on pasencat of a subscription of five (5) Ehillings.

2. Should those joining as nhore obtain an extension of leare, thes can extend their "Tenyporars dembership" ou the pagucnt of an achlitional 5s. for ang period not excecding six months.

3. JIembers of the United Serrice Institution of India procecding to the Unitch lingdom on "Furlongh," or leave excecling six

Temporary Niembers or Furlough, 10s. per aruun witlout, and fll per annum with, the Journal, on personal ap: plication. montlis, sh:ill be permitted to attend Ieetures and use the Ileading Room, Sce, of the Rogal United Sorsice Institution on payment of 10s. per nnnum. Should they wish also to receire its Journal (which ean only be de. lirered bs the Secretary on personal npplication, or to an. authorized agent, without incurring postege charges),' an aduitional aunual payment of 10 s. will be necessng.

4. In the erent of Tcmporars Jembers, under paragraph 1, obtaining an extension of lease for six montlis, and wishing alsn to obinin the Journal, ther can do so on payment of eftecn (15) shillings in nddition to the firo slillings alrearly paid.

5. All the ahore subseriptions to be paid in adrance, and admission ns a "Temporary Jiember" to tilke place on pajmeut.

6. The abore rules will apply to both Life and dnnual Jembers of the United Serrice Institution of India.

\section{B. Proprosed that-}

1. Members of the Rojal United Serrice Institution shall, throughnut their

Members, Rogal United Serrico Institution in India, R. 5 per an. num, and Joumal. serrice in India, be entitled to be in all respect s (iucluding receipt of Journal withnut ext ra pjsment) Jlembers of the United Serrice Institution of Indiu on pasment of an Anuual Subscription of Rs. 5 (in adrance). 


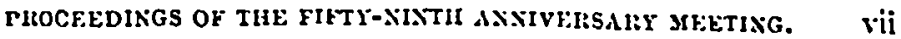
C.-

1. Any Member of either Institution rill be cntitled to obtain the Journal of the other on payment (in adrance) at Members' prices.

2. The Secretariez of both Institutions will iuterchange lists of Mewbers, made up to date, poriodicalls.

\section{Comesponding Mexiens of Council.}

12 On the 1st January, 1890, the number of ('orresponding Members of Council was 234.

\section{Gold Mrdal.}

13. Six Essays hare been received in competition for the Gold Medal, tho subject being-

"The Maritime Defence of the Onited Kingdom (including its Colonies and Dependencies) and its Trade, in a $\mathrm{War}$ with a great Maritime l'ower, showiug the fleet considered necessary and its disposition."

Admiral Sir George Willes, K.C.B., Captain Bedford, C.B., d.D.C., R.S., aud Captain Long, A.D.C., R.N., kindly undertook the duties of lieferees, and their decision will bo mado linown to this Mecting.

\section{Subject for the Militaib Fssay for this Ifalr.}

"The 'lactical Operations of the future (including questions of Supply and 'l'rausport of Ammunition), as affected by the introduction of Magraine Rifles, Macline and Quich-firing Guns, and Smokeless Powder."

The competition is open to Members of the Institution, and to all who are eligible to become Members.

\section{Mevinens of Council.}

15. In accordance with the Bje-lar passed at the last Annual Geoeral Nenting the following Members retire, having served threo years on the Council, viz. :-

Rear-Admiral P. II. Cotous.

IInjor-General Sir Wintrax Crossuras, K.C.M.G., MI.P., lato R.E.

Colonel D). Ifrese.Home, late Rojal Horse Guards.

The Council submit the names of fire Members, from which racaucies may be filled up. The first three on the list are proposed for immediate clection, vi\%.:-

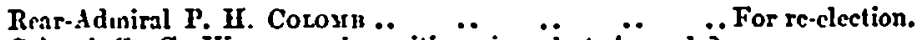

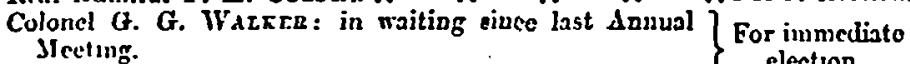

It.Colunel N. I. Watroed, h.p., R.A.

Jiajor.Gencral E. H. Curire.

Coloncl R. N. DATsos-Scotr, h.p., R.E. 
viii PROCEEDINGS OF THE FITTY-XINTI IXNIVERSARY MEKTING.

\section{Coxci.usios.}

In concluding their Report, the Council express their regret that the number of deaths and withdrawals has more than counterbalanced the number of new Membess, and that they have had to strike off the mancs of 28 Members for the non-payment of their subscriptions after. repeated applications, thus further reducing the number on the rolls ai the Institution.

'lley cimmot but hope, howerer, that when the question of :I new house is faronrably settled, a generous support will be given to the Institution, in order to make it more worthy of the Naval and Military Services of the couutry.

Yiutr:Irat.r. Yann, 13 th Feliunty, 1890.
By Orler.

13. BURGESS, Cartain: 


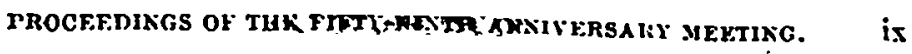

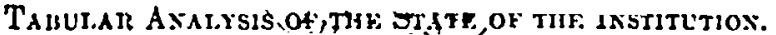

\begin{tabular}{|c|c|c|c|c|c|c|c|c|c|}
\hline $\begin{array}{c}\text { Ycar. } \\
\text { Jet Jan. } \\
\text { to Jist } \\
\text { Dece. }\end{array}$ & $\begin{array}{c}\text { Annual } \\
\text { Sulue. } \\
\text { recedired. }\end{array}$ & $\begin{array}{c}F_{\text {.n- }} \\
\text { trance } \\
\text { Fess. }\end{array}$ & $\begin{array}{l}\text { Inconere } \\
\text { (Irom all } \\
\text { goutrece). }\end{array}$ & 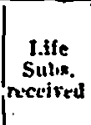 & $\begin{array}{l}\text { A mount of } \\
\text { Stock. }\end{array}$ & $\begin{array}{l}\text { Inresical in } \\
\text { thie pittr- } \\
\text { cliass of } \\
\text { bouls, sce. }\end{array}$ & $\begin{array}{l}\text { No. of } \\
\text { Vols. In } \\
\text { Library. }\end{array}$ & $\begin{array}{l}\text { No. of } \\
\text { sle pili.er: } \\
\text { on the } \\
\text { 31, thec. }\end{array}$ & $\mid \begin{array}{l}\text { Number } \\
\text { a } \\
\text { Wisturs. }\end{array}$ \\
\hline & $£$ & 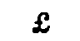 & $\mathfrak{E}$ & $\mathfrak{x}$ & $\mathcal{L}$ & $\mathfrak{L}$ & & & \\
\hline 1831 & 651 & .. & $C 5:$ & 1,104 & .. & .. & .. & $1,13 i$ & .. \\
\hline 1832 & 1,116 & .. & $1,1.16$ & 973 & .. & .. & .. & $2,69 !)$ & .. \\
\hline 1633 & $1,10 j$ & .. & 1,150 & 692 &. & .. & .. & 3,341 & .. \\
\hline 18.31 & 1,500 & .. & 1,519 & 583 & 1,100 & .. & .. & $3,7 \cdot 18$ & 13,370 \\
\hline 1835 & 1,150 & .. & 1,071 & $36 \mathrm{f}$ & 2,430 & .10 & .. & 4,155 & 8,537 \\
\hline 1830 & 1,570 & .. & $1, \mathrm{GS}: \mathbf{3}$ & 330 & 3,747 & 43 & .. & $\$, 069$ & 8,521 \\
\hline $183 i$ & 1,540 & .. & $1,7 \cdot 17$ & 222 & $4,7 \cdot 17$ & 160 & .. & $4,10.4$ & 10,007 \\
\hline 1839 & 1.462 & .. & 1,031 & $\Sigma 30$ & 5,500 & 216 & .. & 1,175 & 15,788 \\
\hline 1839 & 1,399 & .. & 1,565 & 165 & 5,500 & $29 ?$ & .. & 4,186 & 16,248 \\
\hline 1810 & 1,365 & .. & 1,525 & 189 & 5,500 & 416 & 5,500 & $1,25 j$ & 17,120 \\
\hline 1811 & 1,450 & .. & 1,613 & 186 & 6,000 & 243 & 5,850 & 4,243 & 10,121 \\
\hline 1812 & 1,373 & .. & & 1.14 & 6,100 & 373 & 6,150 & 4,127 & 21,552 \\
\hline 1813 & 1,209 & .. & 2,191 & 140 & 0,700 & 237 & 7,000 & 1,078 & 27,056 \\
\hline 1844 & 1,271 & .. & 1,108 & 112 & 3,000 & 298 & 7,850 & 3,968 & 22,707 \\
\hline 1815 & & .. & & 28 & 1,500 & 127 & 8,100 & $3,9 \mathrm{SS}$ & $21,6 \pm 7$ \\
\hline 18.4i & 1,998 & .. & 1,156 & I3S & 1,500 & $7 t$ & 8,410 & 4,031 & 32,855 \\
\hline 1817 & $1,31 \cdot 1$ & it & 1,502 & 132 & 1,700 & 37 & $\therefore$ & 4,017 & 38,694 \\
\hline 1819 & & 57 & 5 & 48 & 1,700 & 85 & $9,0.11$ & 3,947 & 37,140 \\
\hline 1810 & 1,176 & 72 & 1,375 & $8 t$ & 1,150 & 59 & 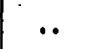 & 3,570 & 33,333 \\
\hline 1850 & $1,1.41$ & IOR & 1,201 & 103 & 600 & 36 & .. & 3,948 & 33,773 \\
\hline $15 \overline{1} 1$ & 1, & 131 & 2 & 60 & 606 & 3 & 10,150 & 3,185 & 02,173 \\
\hline 18.52 & & 133 & & 114 & 200 & 43 & 10,300 & 3,078 & $2 u, 609$ \\
\hline 1853 & 1,213 & 319 & 1,681 & $2 \pi 4$ & $52 \mathrm{~S}$ & $\$ 1$ & 10,420 & 3,251 & 25,952 \\
\hline 165 ! & 1,200 & 133 & 69 & 120 & Gil2 & 95 & 10,587 & 3,171 & 22,661 \\
\hline $165 \overline{5}$ & & $10 \bar{T}$ & & 120 & 653 & $5 j$ & 10,760 & 3,131 & $1 \cdot 1,7$ \\
\hline 1850 & $1,21 \mathrm{G}$ & 107 & & 156 & 501 & 17 & 10,832 & $3,20:$ & $16,18 t$ \\
\hline 1857 & 1238 & 176 & 1,037 & 78 & 1.033 & 10 & 10,900 & 3,165 & 12.755 \\
\hline 1853 & 1,318 & 221 & 2,102 & 100 & $43 \mathrm{~S}$ & 31 & 11,062 & 3,216 & 25,717 \\
\hline 1859 & $1, \mathbf{5} 26$ & 19.5 & & 512 & 916 & 70 & 11,320 & 3,344 & 29,739 \\
\hline 1850 & 1,901 & 298 & & 397 & 2,178 & 114 & 11,517 & 3,518 & 29,011 \\
\hline 1861 & 2,122 & 305 & & 260 & 2,846 & 9P & 11,812 & $3,6 \div 9$ & 23,296 \\
\hline 1862 & 2,290 & 212 & $3,12 \bar{i}$ & 239 & $3,1 \div 8$ & 100 & 12,026 & 3,797 & 27,215 \\
\hline
\end{tabular}


Apresplx $\mathrm{A}$-(continued).

Talmular Afalysis, dec.

\begin{tabular}{|c|c|c|c|c|c|c|c|c|c|}
\hline $\begin{array}{c}\text { Year. } \\
\text { 1st Jan. } \\
\text { to } 31 \text { sts } \\
\text { Dec. }\end{array}$ & $\begin{array}{c}\text { Annual } \\
\text { Subs. } \\
\text { receired. }\end{array}$ & $\begin{array}{c}\text { Ev. } \\
\text { trance } \\
\text { Fees. }\end{array}$ & $\begin{array}{l}\text { Incoms } \\
\text { (from ill } \\
\text { sources). }\end{array}$ & $\begin{array}{c}\text { Life } \\
\text { Sults. } \\
\text { recelsce. }\end{array}$ & $\begin{array}{l}\text { Anoount } \\
\text { of Stock. }\end{array}$ & $\begin{array}{c}\text { Inrested in } \\
\text { the pur- } \\
\text { chasc of } \\
\text { Dools, dic. }\end{array}$ & $\begin{array}{l}\text { No. of } \\
\text { Yols. in } \\
\text { Library. }\end{array}$ & $\begin{array}{l}\text { No. of } \\
\text { siembers } \\
\text { on the } \\
31 \text { stDec. }\end{array}$ & $\begin{array}{l}\text { Numsct } \\
\text { of } \\
\text { Visitors. }\end{array}$ \\
\hline & $£$ & $\mathfrak{E}$ & $£$ & $\boldsymbol{x}$ & E & $f$ & & & \\
\hline 1863 & 2,379 & 218 & 3,100 & 405 & 3,583 & 143 & 12,296 & 3,847 & 18,150 \\
\hline 1864 & 2,425 & 215 & 3,253 & 222 & 4,516 & 116 & 12,700 & 3,902 & 17,276 \\
\hline 1865 & $2,43 j$ & $15 t$ & 3,467 . & 235 & 4,801 & 137 & 13,000 & 3,895 & 18,253 \\
\hline 1866 & 2,435 & 157 & 3,488 & 299 & $5,4 S 6$ & 150 & 13,337 & 3,801 & 17,067 \\
\hline 1867 & 2,431 & 141 & 3,467 & 203 & 5,732 & 140 & 13,800 & 3,523 & 17,211 \\
\hline 1868 & 2,116 & 181 & $3, \mathbf{5 3} 4$ & $29 \pi$ & 6,396 & 119 & 14,100 & 3,812 & 16,417 \\
\hline 1869 & 2,363 & 165 & 3,495 & 233 & 6,653 & 232 & 14,660 & 3,792 & 15,947 \\
\hline 1870 & 2,376 & 178 & $3,4,93$ & 333 & 7,313 & 140 & 15,055 & 3,831 & 18,654 \\
\hline 1871 & 2,455 & 237 & 3,677 & 539 & 7,748 & 202 & 15,501 & 3,022 & 19,420 \\
\hline 1872 & 2,620 & 336 & 4,111 & 713 & $8,92\}$ & 192 & 15,701 & 4,116 & 19,773 \\
\hline 1873 & 2,770 & 295 & 4,316 & 535 & 8,4 ก5 & 222 & 16,227 & 4,276 & 18,183 \\
\hline 1874 & 2,819 & 216 & 4,491 & 409 & 10,189 & 218 & $16,62+$ & 4,330 & 16,771 \\
\hline 1875 & 2,501 & 151 & $4,595^{*}$ & 469 & 10,721 & $22 \mathrm{~S}$ & 17,000 & 4,308 & 15,960 \\
\hline $18 \pi f$ & 2,794 & 162 & 4,500 & 437 & 11,305 & 171 & 17,700 & 4,320 & 15,543 \\
\hline 1877 & $2, S 40$ & 218 & 4,750 & 526 & 11,725 & 217 & 18,300 & 4,405 & 15,682 \\
\hline 1878 & 2,881 & 231 & 4,700 & 459 & 12,091 & 231 & 18,750 & 4,485 & 17,881 \\
\hline 1879 & $2,90 k$ & 180 & 4,490 & $40 \overline{7}$ & 12,505 & 254 & 19,170 & 4,473 & 15,529 \\
\hline 1890 & 2,962 & 255 & $5,115^{\circ}$ & 5.7 & 12,965 & 240 & 19,565 & 4,531 & $13,0.41$ \\
\hline 1.831 & 2,893 & 233 & 4,067 & $B 45$ & 13,670 & 240 & 19,920 & 4,577 & 12,507 \\
\hline 165? & $2,8 \geq 0$ & 181 & 4,739 & 491 & $14,0 \subset 0$ & 174 & 20,352 & 4,591 & 12,546 \\
\hline $18 S 3$ & 2,832 & 205 & 5,023 & 692 & 15,251 & 157 & 20,658 & $4, \mathrm{C} 2 \mathrm{i}$ & 11,452 \\
\hline 1891 & 2,851 & 172 & 4,950 & 491 & 16,000 & $20 i$ & $20,9 \$ 3$ & 4,613 & 12,338 \\
\hline I895 & $2,85 \bar{T}$ & 181 & 5,121 & 515 & IC,902 & 169 & 21,370 & 4,377 & 12,220 \\
\hline 1SSf & 2,757 & 141 & 4,842 & 358 & 17,492 & 192 & 21,778 & 4,365 & 12,358 \\
\hline 1837 & 2,728 & 141 & 4,893 & 401 & 18,372 & 160 & 22,037 & 4,250 & $10,97+$ \\
\hline 1899 & 2,716 & 216 & $5,238^{*}$ & 512 & 19,705 & 195 & 22,565 & $4,25 i$ & 14,818 \\
\hline 1859 & $2,6 t ; 3$ & 148 & $4,87 \pm$ & 375 & 20,498 & 140 & $23,0-16$ & 4,226 & 13,333 \\
\hline
\end{tabular}

* A legacs of $£ 100$ mas receired this jear. 
Arming:

Detall ô: Axsiugit. Sülśscrubetis

1889.

Pnid for $1889 @ 11 \ldots \ldots \ldots \ldots \ldots \ldots \ldots \ldots \ldots \ldots \ldots \ldots \ldots .2,529$

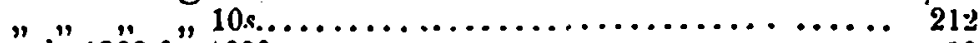

" in 1888 for $1889 \ldots \ldots \ldots \ldots \ldots \ldots \ldots \ldots \ldots \ldots \ldots . \ldots \ldots$. 10

New- Members who joined hetween October and December, $1838 \quad 43$

leaths, and withdrawals of Members whose subscriptions for 1889 haro not been paid ........................ 36

Members two years in arrears with their subseriptions........ 28

Do. in arrears for $1889 \ldots \ldots \ldots \ldots \ldots \ldots \ldots \ldots \ldots$. 26

Deduct, Anmual to Lifo

$\because$

Deaths and withdrawals $\ldots \ldots \ldots \ldots \ldots \ldots \ldots \ldots \ldots$ 124

2,755

" Struck off for non-payment, in accordance witis Section $\mathrm{T}$, para. 6 , of the Byeliws....................... 28

Total ummber of Ammual Subscribers, 1st January, $1890 \quad$. 2, 2,727

Jons l)ix, Accountunt.

Exanined and found Correct29th Jauuary, 1890.

Lrosf.r. G. Dremmosd.

Ej:Nest li. RaitT. E. R. WETHERED, Lt.-Col.

Arrfadix $\mathrm{C}$.

Capital decoust.

Stock.

f $s . d$.

Cunsuls $\ldots \ldots \ldots \ldots \ldots \ldots \ldots \ldots \ldots \ldots \ldots \ldots \ldots \ldots, 16,343$ 16 9

India $34 \% \ldots \ldots \ldots \ldots \ldots \ldots \ldots \ldots \ldots \ldots \ldots, \quad 2,028 \quad 17 \quad 8$

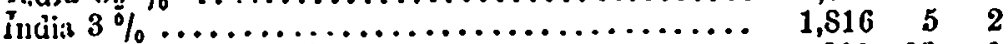

Nottingham Corpn. $3 \% \ldots \ldots \ldots \ldots \ldots \ldots \ldots \ldots \ldots, \quad 399 \quad 13 \quad 1$

$\mathfrak{f 2 0 , 4 9 8 \cdot 1 2 \cdot 8}$ 


\section{ArIr:vix D.}

To the Right Inonourable G. J. Goschen, M.P., Chanecllor of the Eschequer.

Mevonise from II.R.II. the Presilent, Vice.Presidents, Council, and Menbers of the Koyal United Serrice Institution.

1. Your Memorialists deeirc to bring to jour notice the preecnt position of the Rojal United Sersirc Iustitution.

2. The Institution occupies two houscs, which are the properts of the Crown,

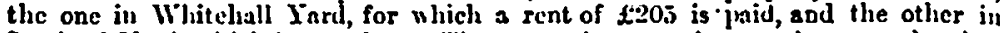
Scotland Yurd, which is rent-free. Tlicse premises mas have to be surrendered to the Gorcrnment at ans time, as regards part at wiil, and as regards the remainder at three usonths' notice.

3. In contemplation of this conlingener, the Treasury intiunated its willingnest to pis the ground-rint of a suitable site for the Institution, less the rent of $\$ 205$ now paid to the Gorernmest, on the condition that the cost of erecting the aew building should be defrnyed by the Institution.

4. On thic assumption that the present site shall be retained, the ground.rent, calculated on the current murlet ralue of the land in the localits, would be, in round numbers, $£ 1,300$, and deducting from this sum $£ 200$, the amount of rent,

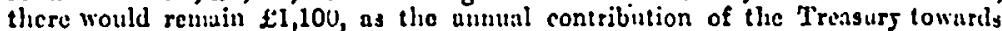

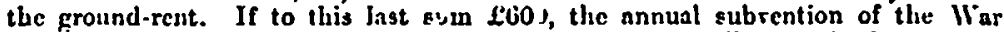
Otliec and the Adlniralts, is adlded, the ausount of 21,700 will be nrrired at as the sum to which the Gorernment will stand p!edged in the cvent of the aborementioned undertaking on the part of the 'Treasury being carricd out.

5. In this case the responsibility of providing the new building would rest upon the Intitution; but its funds have been shown, in recent correspondence, to be insuficient to inect such an obligation, and it is, therefore, necessary that some ot her armingenent ghould bo made.

G. In this riew it is now suggested that the Gorernment should construct the new building and grant the free use of it to the Institution, whildet retaining in its own bands the full rights of onwership.

7. The searls espense of this felieme th tlic Gorernment would be: (1) 1000 , the interest of the cost of the new building, estimated at 130,000 ; (2) $£ 1,300$, the ground-rent of the site. Which would be forerone; (3) $\& G$ o, the annual subrention of the War OMice and the Adniralts, traking a total of $2^{22} 2,800$. But, on thic ut!er hand, the Institution, when placed in possession of accommodation suited to it. requirements, miglit reason:bly anticipate inercased subscriptions from the Serrices, and, if these were forthcoming, the necessity for an annual subventior might possibly ecasc, and then the anumal cburge on the public finances would be decreased

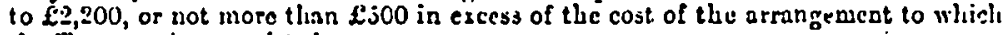
the Treasury is committed.

8. It sliould be further borne in anind-1st, That the extent of the Gorernment aseistance, which this scheme contemplates, would not realls be greater than thite Flich the In-titutim lass received for sereral ycars past, namels, free accomalada. tion and a sunall monep grant; 2ud, That ihe following Sucieties: the Royal Sucicty, the Socicts of Antiquaries, the Linnean Societ r, the Chemical Socicty, the Roral Acadeuy of drts, the Geological Suciets, and the Rojal Astrouomical Suciety, when displaced from Someret lIouse, owing to the premises being other. wisc appropriated, had frec necommodation provided for them by the Gorernuent, and it is cuntended that they hal not grenter claims for consideration than the Rujal United Scrvice Institution.

0. It remains to be statel that the Mannaing Committen of the Rojal Finginerers' Institute hare intimated their desire that, when a new houso is built for the Jlojal United Serrice Institution, it sliould bo mflefeiently large to accommodat: their Head.quarters Ijibrary, the books of rhich nre now ecattered through ecreral roonis and passages of the Wnr Onice, in which about 2,000 square feet of wall epace are thus occupied-a moet inconrenicnt arrangcment, from whaterer poiut it 
may be regnarded. This proposal has been farourably entertained by the Council, who are of opinion that many adrantuses would accerue from the librury of the lloral Iing necrs' Institute being under the same roof as the Roral United Sirrice Institution, and the scheme hins since been upprored by His Rugal Higliness the Colonel-in-Clief of the Royal lenginecrs.

10. Your Jemorialists are aware that thero mas be dificultics in the war of proriding a nem building for the liojal United Scrvice Institution; but, if sucli be the case, thes huve 110 hesitation in urging the dorernment to Lire an official promise that on sestuming pussession of the present prenises it will find for the Institution other accoumo:Iation, rent-frec, on a suitable site. $\Lambda$ definite assur. :uce to this effect would in some neasure relieso the Institution from the injurious results of the present uncertaints of its position, and enable it to appeal witl some prospect of sucesss to the Naval and Military Services for the amount of support to which it mag fairly be considered entitled, but which they now withlsold from it, owing to the unfortunnte circumst:ances in which it is placcd.

11. This would, of coursc, eftert no little improrement in the present state of affirs, but jour Wemorialists, while admitting this, consider themselses bound to represent that the work of the In:titution is scriously impedel by tlic rery dilispidated condition of the tro houses which it occupies, and by the insufficicncy of the sceommodation which ther afford. The exhibits of the Mluseum and the books of the Librirs hare incressed of late jears to such an extent that proper syrace cannot be found for them, and the interest now taken by the publio in the discussions periodicalls enrriel on, attracts to the Lecture 'Theatro numbers for which it is often difficult :o proridle.

12. It is thus clcar thint yoro commodions prenises than those which the Institution now holds are urgently reyuired, if its pist splere of uscfuluces is to remain inimpaired. To that ussfulnes, as appeary from the sccords of the Institution, frequent and rers etrong testimong has been bone, not only by War.al and Mrilitary Otfieers of high rant and great experience, but slso hg Statemenen who have filled the. most important offices in the gorernment of the limpire, so that it is not necessary to lay further stres 3 on that point on the present excession, the more ".pecialls as sou, Sir, rlien at the head of the Nirnal Administration of this country, must havo lad nang opportunities of obserririn what the Institution hils already done fur the juprovenent of the Army nnd the Firs, and of jullyin: livir much more may be expected fron it when it shall hare bech placed on a sutis. factory footing in regatril to necommodation.

liogal United Serrice Institution,

(Signed) GEORGE. Whitchall Yard, $29 t h$ June, 1859. 
APrexidx E.

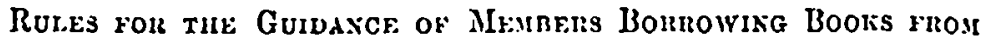
THE IMULARY.

The Rules of the Iilorary, dated 6th July, 1887, nre hercby can celled, and tho following are substituted to tatic effect from this data.

1. Any Member in the United Kingdom, and who is not in arrears of his Subscriptiou, shall, nul payment in advance of 10 s. for twelve months from date of payment, be permitted to borrow books from tho Library subject to the following Regrulations.

2. The abovo liulo will not, as regards paymert, apply to Officers employed in the IVar Office, Admiraity, India, Colonial, and Foreign Ofices, who may desire rootks from the Library to assist them in their professional duties

3. All charges for the transmission of books, from or to the Iustilutiou, slatl be paid by the Members borrowing.

4. Books which canuot be replaced, and those of great value and rarity; are not to be issued on loan, neither are Books of liefurence, Atlases, Maps and Charts.

5. A Member borrowing a book from tho Lilurary shall be responsiblo to the Institution for its safety and good condition from the time of its leaving the Institution, until it is received back by the Iibrurian : in case of loss, damagre or defacement by marking or in any other way, ho shall replice tho same, or mike it good, or shall furnish another copy, or pity the value of the entire rrork of which it mily be a part, as niay be directed by the Council.

6. Members borrowing books are not privileged to leud them.

7. The number of Volumes at any one time issued to st Member shall not exceed four; this will not include Maps issued with the Volumes.

8. Books borrowed from the Library are not to be detained longer than one montl.

But should a work be applied for by a Mlumber for a longer period the Idibrarian is authorised to extend the period of issue to a second month and subsequently to a third, provided the work is not recquired by another Member; after the third month the return of the work is compulsory.

9. Non-compliance with any of the above Rules will render a Member liable to the forfeiture of the privilege of borrowing books.

IBy order of the Council,

Royal Unttev Srinvic: Institutiox, JUIIN DAY, Librarian. 6th Norember, 1889. 


\section{General Grorge Enskixe:-}

MIy Iord,-Perbaps before Jon proeced to deal with the sevcral resolutions which you have on the Agenda paper, jou will allow me, as Chairnan of the Council, to say a few words supplenentary to the Report which we hare just heard rend. I think it would be litting in nie, as a preface to whint. I liate to say, to gire expression to the thankfulness witich my collengues nod myself fecl, that we hare litd no accirlene to life or limb from the delapidated state of the building in which we hare hand to carry on our work. How long this junuunity may last, I nun not prepared to say. I can only hope that there will be no ecrious disister before no emerge from this tenement irto a better one, but when will that be? That is a question which is cecrsising, und has long excreised, the winds of all the fricucis of the Institution, but I um sorrs to say that the Council cannot jet gire nuy definito answer to it. At ans rate, I can gire this mesting, with your permission, a few detuils of what has been done, during the last year, with regard to the future of the Iustitution. We occups two housc3, both which are the properte of the Crown, and in both ne aro tenants at will. One house is rent free, for the otlicr we p:is \&:205 a year as rent; but on the other hand, the Gorernment gire us an annujl subrention of $f 600$. Therefore, to put the matter shortly, we bare at the prescut time frec accommodation, and an allunance of 2395 a yetir. I hare side that we ure fenants at will, and from time to time we bare hand notice to quit. At the present time we ure in that predicanent, but in rien of our haring to turn out froun our present premiscs, the 'Treasury, some time ago, promised that thes would pay the ground rent of a stitable site for the Institution, with a proviso that the Institution should build the house that would be required. Some time ago-only a fer Jears ngo-a strict scrutiny of the finanecs of the Institution showed vers clearly that we were not in a position to do that, and accordingly, on the gith of Jonuars, 18ss, the Council decidicl that a latter should be rritten to the Treasurs, explaining thit fact and ashing the Government to build the housc for us when wo should have to racate these premiscs. So notice wus taken of that letter, and in consequence we repeated the application on the 12th of $A$ pril last jear. 'That did not seem to produec unr effect, and accordingls we tnetnorialised the Chancellor of the Exchequer, on the 29th of June last. It was intended, al first, that wo should present the memorial bs means of a deputation, but the Chancellor of the Fixchequer demurrel to thit course, nnd it was not taken. The memorial, howcrer, was supported by a large and induential number of weubers of Parliament; thes took the catse up rery warmly. Thes held two unectings with a vicw to giving expression to what thicy thouglst on the subject, and the second mecting was attended by 3Ir. Stauliope, the Scerctars of State for War, and jourself, my Iord, as First Lord of the Adniralte, and I beliere I um right in sasin", that MIr. Stanliope nud yoursclf promiscd io represent the claims of the Institution in the strongest way to the Chancellor of the lischequer. The press also took up the cause of the Institutiou on that oceasion, and sereral of the leading journals wrote sery strong in its belaale. While all this was going on, the end of the l'arlianentary session approached, and we all lnow what tleat meuns with regard to tho work of the Jfinisters of thic Crown. Mr. Goschen was sorely pressed with his worl, and on the 3rd of Scptember he, through his private secretury, addressed a letter to me, as Chairman of the Couacil, to say that he could not possibly take up the applica. tion containcd in the memorial until after the racation. Of coursce, a consider.uble delay ensued. and the nest erent that I hase to speal of, is an interriew which I b.d with Sir Re, inuld ITelby, whon. I think, I nas describe correctly as the permanent head of the Treasury. II had had the question of the Institution deputed to him by the Chancellor of the Frchequer, and ho desired to lase an iuterriew with me on the subject, so that we might discuss the matter. We niont inlo the question rery fullr. Of course I need not tell my colleagues on the Council that I pressed the cjaims of the Institution in the strongest way I possibly could, nnd I flatter myself that I made some impressinu on Sir Reginalu Wielby. I do not mean to say that I conrinced him. He is much too good an official io confess that that was the case. Howerer, he promised to represent what I had said to the Chancellor of the Eschequer, who at that time was in tho country; axd 
Ine snicl that the next step would be to call upon the Onice of Works, to report to the Treasurs refrarding the sites that would be arailable for the Institution, and ulso with reg.red to the ejst of a new building. I line been made awirs that that Report has been rendered to the Treasury, so that I presume that lhe Chanecllor of the Eschequer has before him at the present time all the information which he rejuires. It inay appear, perlasps, that the Council has been rather importunate in their deslings with the Tressurs, but I do not think that we nedd to mite ang npologr on that acconnt. We nre not pressing our indiriclunl claims in matters of personal interest, but adroenting the caluse of an Institution which has prosed itself of the rery grettest utilits to the two Serrices-the Arms and the Xary-sal not only that, but which has shown itself one of nation:l importance. Tlie fact is that our records teem with testimonials to thith effect, not only from uaral and military onlicers of distinction, but also from ministers of the Croirn and statesinen of all shailes of politics, and eren from men of scienee und inventors. I hitre siid that we lizie asbed the Gorernment to build us a new house when wo hare to tirn out of the brescut primiscs, but that is not, I think, quite so great a deonand as it would at first sinht appear, becausc tho properts will not he linniled over th tho Institution. We should ro:nitin in the new house, according to the proposal of the inemori:l, as tenants at will, so thitt if tha Government should wish to turn us wint at any tiuse, they would lisre the poirer to do it. We merely renicest that they will contimue to us the same nssistanee as they have rendered up to the present fime, thist is, frec acroninuollation, which was given to seren other institutions, which I need not n:mo just now, when they were turned out of Senerset Honse. 'The Goversment ou that occusion prurided for thosc societies free neconmochation, as they had prerionsly to that change. I bappen to bnow that this question of erictinn is cropping up again. We hare becu long thrcittened, but every jear, of contrse, brings us necurer to the final catistrophrs; aml I would ask, what is to be done when that erent comes? If we are deprired of this house, we shall requiro annther. Wo hare nlreuly shown that oue fintunces do not iulmit of our building a housc. Then, will the Gorernment do it for us? That remains to be scen. I am quite sure of this, that if the Gurernument proposes to do so, tho necesz:ars cxpendituro will bo rehe.rfully roted in I'arliament, and the action of Perliament in that direction will be cordially endorsed by public opinion. Therefore, I think, we hare somo reis in to hope that our weinurial will nect with the suecess which we think it descrves. I hare no mure to sas on that subject, and I will not detain you more than 2 ninuto by mentionine two unatters which are of Iess importance, but still deserse to be brouglit before the meeting. One is that the Council, during the last jear, lasse made arrangements for proriding members in the Institution with light refreshments, so that (her will hare food for the boly here, ns well as fool for the nimd. The next is that Council are considering, whether it is possible to re-urrange the contents of our muscum in such a wny as to procurc mnro sccommodntion for the mewbers who risit the Institution. It is not an eass mitter to do that in the premiges which wo now occups, but we hope that it will be efected; and if so, ilioso gentlemen wbo find thist they can prosecute their stuilics nore effectually when they hare the use of tobacco than without it, will be able to hare their cigar, or, perhasps, a pipa, withoust incomnoding anjone who objects to smoking. MJ Lord, I lase nothing further to sas.

\section{Admiral sir Riche Ied V. HAMn.Tox:-}

IIs Lorda and Gentlemen,-It gives ne rery great pleasuro to propose tilie first resulution, namely, "That the Report, now reir, bu ndopted, and printed for circulation among the menibers." The Report is so eatisfactory that it speaks fur itself, nnd, there'ore, it is quite unnecessary for me to sas mueh on the subject. I would first like to call your attention to the satisfactory cliarseter of the finances. Wo harn increaned our investments. If there is angthing to soft n the hard hearts of the Treasurs, I think it outht to be the knonledge that in that respect we are all right. Thio subjects discussed during the last jears lure been vers equally divided over tho brinches of the Service, nnd I aun rery glicl to ece amengst tho eight naral subjects that huve been discussed, sereril have been brought formarl 
by oflicers of the Rescrse Forees, showing the interest that ther tate in thess questions. The ndditions to the library are nost salisfactory. With regarl to tiro leuding Library, I can mrself testify to the benefit that I hare derired from it during the last year, und I lope nest year the finances will be in a more satisfactory state than they are wow. The nen s5stem of giving professional assistance t: oticers of the Arms and Narg has also been rerg benclicial, nnd there is no duttbt about the very great ralue of the naval models that hare been added to the Bfuscum during the jear, and I hopo the Council will tabe steps to iucrease their number. I beg to move the resolution.

\section{General Sir BvadchajuP Walker:-}

My Lords and Gentlemen,-In rising to sccond the adoption of the Report, I liave really littlo or nothing to acld to tho sery able préeis which tho Chairman has giren of the most important subject under our consideration, which is the provision of a new building. I auz sorrs to say-for the first tine sinec I lare been a enember of the Council, now eleren Jears-there has been a rery strong difference of opinion as to the mode which should be udopred in bringin: this question to tho knowlcdge and the consideration of the Clancellor of the Fisclicquer, but I for one, as roting in the majority, entirely supported the proposil to leare this most delicate matter in the hands of our Chairuson. I can only say, speaking iny own opinion, that I do not think the tact and the discretion with which our Clıniryaan las conducted the busincs3, could possibls lanre becll surpasscd. Adluiral Hamilton has adverted to the points which he considered worthy of remark, sind The has left me little further to say on the subject. I sbondd, with hiw, wish to recommend to the offecers of the Serviecs the use of our Lending Library. It was an admirable system when introduced, and I hope that when the next report is read to an audience in this theatre, wo shall find that the number of members who hare insde use of it, has been rery largely increased. I hare, therefore, pleatsure in ceronding the proposal that "the Rejort, nor read, to adopted, and piriuted for circulation awong the menbers."

\section{Colonel IJOXsDale LALE:-}

Lord Gcorge IInmilton and Gentlemen,-I rișc on the present occnsion to offer some remarks with regard to the Institution and the Report, and before $I$ do zo allow me fo inention some of m5 clains for renturing to trespass upon your lordsbip's attention, and upon the attention of gentlemen lecre present. For seren Jears I have had the honuur of being a member of the Council, and I am still a member of the Conneil, and, thercforc, I ought to know sowcthing about the working of this Institution. I ought to knom and to be able to distinguish between tho dificulties which lie in the way of our progress and which cun be orercome, nnd those which cannot be orercomc. Then, again, for nearly double that time 1 lawro been able to give a considerable amount of time and labour to the Jourual, as the Honurars Fiditor of the "Occasional Notes." I Lare also, I believe, brought a bout fifty fresle members to this Institution. I merels mention these facts, gentlemen, to show that anything that I viay say that may go agatinst the specehes we hare just heard, and which mias be apparently in opposition to the majoritr of the Council, is not in the nature of factious opposition, and that I hare dono nis best for mans jeurs in the interests of the Institution. Sow, Sir, I hare been talen by surprise by the departure from precedent which has been initiated bs ws friend, Grnersl Erskine, on the present occission. Hitherto ure bate alurass bad the motion for the Report proposed and seconded, and then the discussion took ylace, but on this oceision, prior to the proposal for the acioption of the Report, the Chairman vot only has interrened, but l:e has told us a great deul which is not in the Report at all. IIo li.ss giren himself an addendum to the Report, and if we, the minority of the Council, had known that this was to take place, then perlnans we should hare coure prepared to inect him, becausc, ns both Oeneral Ershine and Sir 1Beauchaup Walker would admit, his remarks refer to the rers subjects upon which there was a rery warm and strongly expressed diversity of opinion in the Council, and $I$ an afraid that in the course of my obserrations I shull hare to tale esception to the vicu of 


\section{xviii PROCEEDIGG OF TIE FIFTI-NINTH ANNIVERSARY YEETING.}

what has bappened, as expressed, perhaps, by those tro distinguished officers. 13ut, howerer, we will leare that for tho present, and $I$ mas say further that I ain one of the firmest belierers, perhaps orer-sanguine, in the potentialitics of this Institution. I beliere that the poriers of rendering serrice, not only to the Army and $\Lambda$ ary, but also to the nation at large, which this Institution possesses, are enormous, but unfortumately thes are latent, thes are not being esercieed. I also am aware that there is tirrougliout, not ouly both Serrices, but in the country generalls, a rery strong fecling in farour of supporting this Institution to the rery utmost, but I also know that there is in the Army, at all crents, a deep and growing disaatisfac. tion with the was in which this Institution carries on its work. Gentlemen, I am af raid I cannot impress my collengues on tho Council with that fnct, and thes think that I am somewhat drawing on my imagination in this matter, but I know that there are two members of the Council hero who are on the Actire List, and not on the Retired Lisl, as so many of us on the Council are, and I hope that they will bear me out in eaying that the Serrices at large are dissatisfied with our present position of what I mas call catileptic incrlia. The Arms beliercs a grcat deal more might be done in some way or other, and they are waiting to sce us do it. Now, gentlemen, wo are really in a rers grare crisis of our affairs. We are going to the Gorernment for help, and let us see when the Gorernment call for the Keport, as they naturally do, what sort of Institution it is that they hare to help. They look nt the Report, and they find that first of all it is stated that there is a loss this year of between trenty and thirty members. Well, Te are liable to fuctuation, and if it was only one searit would not matter, but if sou look ba $k$ at the Reports from 1852, I think you will tind we hare bcen eteadily going down in spite of the good feeling which is entertained for us by the Serrices. And then thero is a more astounding fact still. If jou look back to 1841 , you will find that our numbers at tho present time arc ncarly identically the same ns the numbers in the yenr 1811-fifty years ago, and that not urithstanding tho cnormous increase in interest which is taken now-adays in professional matters, by both the Army and Nary, notrithstanding the enormous number of possible subscribers to the Institution which has been created by the institution of the Volunteer Force. Although our,percentage in $1841 \mathrm{may}$ harc been a eatisfactory one as to the percentage of actual subscribers and possible subscribes, the percentage now must be deemed to be of a most unsalisfactory character. sccing ? liat we hare made not one step in the ras of progress since 1841 . Then, with regarl to the museum, about which we hare heard so much, and which has been ralued lately at some fabulous price, I find eren that is ceasing to utfract. The number of people who came to see it during the last year was 13,000, and there are only ten sears out of the whole fifty in which so few hare been to see it. The fact is it is a museum of antiquities. Instead of having here only things which are applicable to the present das, which members of the Voluntecr, the Mrilitia, and the Regular Forecs could sce, without going to Chat ham and elscwhere; we hare nothing bnt eimply nilitary untiquities, and then we expect the Serrices to support us? But, Gentlemen, there is a far more serious matter which I wish to bring to jour notice. There is an item in the Report, that those who do not know this Institu. tion, might read with the deepest satisfaction, but which is to my mind indicatire of vers serious danger to us. It is stated that the eales of the Journal to the gencral public hare incrcased from something like $\$ 375$ to $\$ 160$, or sometbing of the kind. The Secretars was good enough to givo me a list of sales to the general public during the last ten years. I do not know whether they began before that time or not, but at all crents, ten Jears ago, the public demanded $\mathbf{f}^{\prime 152}$ rorth of Journals for their satisfaction. Thus last year was crceptional, owing to there being four issues, but jear after year bas the demand for the Joumal risen, until now it comes to nearly $£ 500$. Why is that? I know the military literature of Europe pretty well, and there is not a single Journal in the whole of Europe which can touch our onn, with regard to its ralue and excellenco. 'Thero is no Journal in the

1 I feel that I hare expressed myself too strongly as regards the contents of the MIuseum, as there are certainly in it some models and wespons of the preacnt das, but to my mind not half enough.-L. II. 
whole of Furope which gircs lectures of such fairly arcrage qualit 5 , and such raluable discussiony, und with regard to that suall portion that I hare to dral with, the "Occasional Notes," it is absolutely the only medium betircen the Army nud Nisy, and the litcrature of forcign countrics. Nor, under these circumstunces, the ralue of the Journal is being daily more and nore apprecisted; more aud more people are buying it, but thics do not join the Institution. People can bus the Journal without joining the Institution. Thes recognise the ralue of this Institution as a great publishing compang and nothing mcre, and thes will not join it as long as they get the Journal, beciuse, as a brother ofliaer of nine expressed it, they do not sce what on carth tlicy will get out of tho Institution by joining it, when thicy can buy the Journal elsershere. There is another point which hus not been mentioned in ans of the previous Reports, and which I an specially ausious to bring to sour attention. There is an institute, a somewhat one fintilar to this, known as the Royal Enginecr Institute, at Clatharn. It is an Institution sirvilar to this, belong. ing to tho Corps of Finginecrs. Nor, nlthough I am an Fingineer mysclf, I may be allowed to say that the Rojal Engineers hare 3 cortain nmount of inducnec. 'They hase ramifications all orer the phec, nnd thes hase, as I sur, a certuin umount of actire influence in different Gorernment departments and elsewhicre. This Institute ibsue their publications in a most admirable nnd economical manner. 'Troo rears ago, in this theatre, at their Corps mecting, thes expressed a desire to establish in Iondon a branch of that Institute. I thought it was a grand opportunity for the United Scrrice Institution, and I got up myself and proposed to inj brother officers that insteal of looking for buildings elsewhere thes should sce whether they rould not in eoune was agiliate with us. They at once joincd with the proposal, and I immediatels afterwards brought it before the Council. It was rers bindls reccired by niy colleanucs, but I do not thiul any of them appecciated ins I dicl the rilue of getting the Engincers under the sibue roof with us. "Ilie general proposition of the Buginecrs was roughly spealing this :-'They offercd us a lirge sum of nones, coming to four figurcs. They said "All we want to do is to get storage for our professionul librars; giro us a storgge for the library and all your inembers shall be free to go in and male uee of it, but our inembers shall not use your Institution unless they belong to it." I saj you could not hase a more generous or liberal offer than that. Last jear, when the Corps met again, I had to tell them that this site question was atill unsettled. Next June they incet again, und then (for I do not think they will wait much longer) I slall hare to bring before them the fact that nothing is settled. They will rers likely go adrift, and *ic shall lose the co-operation of that Institute. I nerely mention these fucts to show jou the crisis in which re are. Now, from the Keport, gentlemen, in spite of what the Chairman says, I put it to you, are we one atom nearer to getting a eite thar we were before? These personal interriexs which the Chniruian of the Council has spoten of, nre esecllent in their way, and I quite agree with whast Sir Beauchamp Winller lits eaid with rergard to the admirable judgment which the Chairman displays in these natters, but I do not beliere in personal intervieus myself. And there is another thing I do not beliere in which lins been laid etress on. I do not belicre in members of Parliawent. Oreat stress wes laid in our Council meetings upou the enormous raluc of the mceting which took place between your Iordship and Mr. Stanhope, and the Army and Nary Conl.mittece of the House of Comulons, and we were told that immense things rould result rers likcly from that. Let us look at it from a comanonsenso point of riew. On that Committce were tro unen, whom I inke as the nutipodes of cach other in politics. Both bolong to this Institution-Sir Williau Crossman nnd Sir John Colomb. Now, do wesuppose that Sir Juln Columb will refusc his support to the Coverratire ministry, or that Sir William Crossman would give a rote of confidence in the miniutry, on accuunt of their not giring support to our Institution? The aesistance of a Parliamentary Committec is nothing at all; we are bound to stand on our own ground.

\section{The Chanksas:-}

l do not wish to interrupt Colonel Hnle in ans remarks he may make in criticising the Report, but I ata bound to suy, it seces to me, that the grcat mise of his 
obscrrations hare nothing to do with the Report. The Report seems to me to be a rery plain statement of facts, and the skctch that was made by the Chairman of the Coimcil is siunply a statement of the procecding 3 which lic and the Council haro talen during the past year for the purpose of bringing the claims of this Institution before the Tre:ssury. No doubt the Anmual Mecting is a farourable opportunity for discussing principles, but I think it is generalls tho custom to give notice of ans question of inportance which is outside the Report, nnd which is intcuded to be raisecl. I do not vish to curtail, unduly, Colonel Hale's speceb, but I am bound to say that ho scems to me to be going into a mazs of matters that ure scarcels germane to tho keport, and if he docs that, it is clear that those who differ from him will claim the libests to follow lim. Under these circunstances, I think you will sce the expedieney of etrictly confining what is eaid to the actual contents ind statements in the Report.

\section{Colonel I OXsodLL IIALE:-}

I accept. your Lordship's correction with the grentest pleasure, only I may ben to Eay that I was not the original offender. 'The Chairm:an of the Council has touched upon rerg controrersial niatter, which has been brought forward, and $m 5$ colleagues in the Council will remember when that was brought forrard, and I did not expect him

\section{Geueral Einskure:-}

\section{I do not know what you refer to.}

\section{Colonel Lossnat.e IIALF: -}

I refer to ono statement about the demur of the Chaneellor of the Exchenuer to receive a dl putation which has been interpreted in different ways, and Sir Betuchamp Wialker raised tho question ubout the deputstion, which was a subject of rery fiers comment brtnceh us in the Conncil. I do not want to go into these questions, I merely explain why I touched unon them.

\section{The Cinamman:-}

I am bound to Eay, that if I thought the Cliairman of the Council ras going to introduce aus natter extraneous or outsido the heport, I should hare felt it my luty to interrupt hin, but in listening to him he scemed to gire a careful chronological etutement of the steps takien bs the Council during the past sear to lay their case before the Treasury. If, incidentully, he toucbed upon any controrcringl matter, I think he did so in such a way as not to proroke discussion, and I think it will be very adrisible in discussing this Report, as I said beforc, strictly to confino our. selres to the facts recorded within it.

\section{Colonel Lossdare HaLe:-}

I will not trespass upon your ruling. I must ear this, with regard to the whole procecdings of the Council for the past Jear, that I bare been in an absolute ninority, but I am rnther proud of that, considering who the other menbers of the minority ure. It has sometimes been a minority of ecren, sometimes of three, and eometimes of one. I might bring thesc matters before this meeting now, but I do not intend to do so. I purposely did not come to raise discussion, but merely to bring before jou, as I hare triel to do, the grare position in which we are at present. I do not wish to bring it before you now, for the renson that this is not a representative mecting of the Institution. It is ono of the regular formal meetings; no notice has been giren of any discussion to be raised upon this grare question, nnd therefore that question lad better bo deforred until we get a really representative meeting. I merels will say, and I really am driren jnto doing so, that $I$ utterly disssent from the procecdings of the Council during the past jear. If $\mathrm{y}$ belief is that, with a more actire and energetic nanagement, we might do, crea with the presesst site, a great deal more than we do. IIf fecling is that the Council lave gone absolutels the wrong way to work in confining their endesrours to obtain a site uncrels to writivg letters to 


$$
\text { - }
$$

offeiuls, and I beg to giro notice that in orler to baro this question properly discusscel, I intend at the nert uneeting of ths Council, on Tucsdis, to ask them to cull a special gencril mecting of the subscribers to tho Institution on some day after Easter, when those members can attend who aro not here at present, members from dldershot, from Chatham, from the Niars, und clscwlure. If the Council decline to accept wy request, then I hare not the slightest doubt that I sluall be able to get 21 members to summon a general mecting, whero the ancmbers will cxpress far murc strongly and openly than liave doue this afternoon, what they think of the prescut and future of the Institution.

\section{General Purcup Surru :-}

Wh orra Colonel Halo a good deal for. haring confinned Sir. Beauchawp Waller's statement that wo are not all agreed ou the Council. I think iny brotter oflicsrs will be extremely happy to hear that erery thing in the Council is not imwe. ciately angecd upon, but that we hare discussions, and sometimes rery marm discussions. If wo lusl not, things, perlaps, would not go on $80 \mathrm{wcll}$. Coloncl Ionstale $H_{2}$ lo bas spolien of tho opinion of the drmy. I think there is a rery strong fecling in the Arny thist we are not going on as fast as we ought to do. Whether that is true, I do not kwow;: I hare my own private opinion upon it. dt any rate, I consider that the number of those who hare withdrama their names shows that that fecling exists. Instead of. oflecrs withlirawing their names, wc ought erery sear to hare a large number joining us in addition. Thers are numbers of Hescre ollicers, who inight not only leive thcir names on tho books, bat also induce others to join. Then we hare a rery large number of Tolunteer offecers who are eligible, and who ought also to belong to us. I think that thero are certain things in the Report which none of us wan call satisfactory. Some laso becn wentioned, and thero are others also whioh are not whit tucy wight be.

\section{- Admiral Cozonb :-}

I bare once or trice been in the minority with Colonel IIale, and I should like on that account to express ny disagrcewesst with the. line which he has taken on this occasion. I do not think that this is the proper oceasion on which to advert to differences on the Council. There hare been those differcnees, and we ouglit to hare them if we are a working Council, but I would ask you, my Lord, to lay to heart the mattcr, which it sccins to mo Coloncl IIule's spcchl live brought out, that is, simply that an iestitutiou under notico to quit, cannot by ans possibilitg pt.t out its full strength.

The Resolution was then put from tho Chair, and dealared carried by a lirge majority.

\section{Colonel Srrickr :-}

My Lord,-In moving the Second Resolution, I hare been requested by thoso interested, to testify to the griat serrice this theatre has becn, not only to tho Serrices, but to the duxiliary Forees. The Home Countıes Volunteer Forces Institution will hold a uceting lere for lecture and discussion one day nese neck. Tery lateiy Colonel Lonsdale IIale lias giren a ecries of wost excellent lectures in this theistre to the members of tae Howe District Tuciteal dssociation. I ullucle to no later date than jesteriay, when the usual professioual lecture was giren at 3 o'clock. At 5.30, this mectint was followed by a largely attcnded lecturs in this theatre to the incmbers of the Ifome District Tactical Association. Sgain, later on in tho crening, at 8.30, I had the pleasure of bcing present at a lecture giren by Cuptain Gall, ou militury brilges, to the Mctropolitan Yolunteer Serjeaut s' Iacticil Association. Fach of these lectures was largely attended, and by almost entirely a different nudience. I doubt whether in the history of this Institution there hav ever baen a larger number of people attending its theatre in ove day than there rere sesterdaj. Howerer dilapidated the state of the theatre mas be from tlie builike's point of vien, to which the Chairman of the Council has alluded, I do nut thint the Institution is at ull dilapidated in the appreciation of the Serrices, or in that of tho 


\section{xxii PROCEEDISGS OF TIE FIFTY-NINTI ASNIVELSARY MERTING.}

militars public. I beg to more "That the thanks of this mecting be giren to those members of the Cuuncil who retire by rotation, and that the following mernber be elccted to fill the racancies, riz. :-Resr-Adniral P. II. Colomb, Colonel G. G. Vialker, and Licut.-Col. N. L. Walford, R.s., for immediate election, and that the fillowing names of nembers bo adopted from which to eelect in cases of racancy occurring in the Council, riz. :-Xlajor-Oencrul E. II. Cliro and Colonel K. $\mathrm{K}$. D:tw:on-Scott, R.F.".

\section{Captain Por, R.N.:-}

I beg to second the resolution 80 ably proposed by Colonel Straces. On the part of tho Nary. I can confirm nll that ha has Eadil as to the adrantoges offered by this Institution. I think that in the Nary the sounger nfficers are joining mote and woro erery year; we all try to get thein to join, and I am sure thes bencfi themsclres and the Scrrice rery largely by joining.

The Resolution haviug been put from tho Chair, was uuanimously aclopted.

\section{Admiral Sir Moustox Stewant:-}

MIy Lord, when I endearoured to fnd refuge in this dilapidated building from the suow outside, I was surprised to find that $f$ was connected with the lionour of proposing a Resolution, and I am happs to 525 it is a Resolution on which I am suro the feeling will be so unanimous, that there will be no opening for discussion. The Chairman of the Council, in lis rery clear und able addresss, has giren us a proof of the great ralue of a sound and healtly bystem of examination into financee. If it had not been for that examination, this Institution inight haro lauaclied out juto great crpenditure which it could not have offoricd. It is not necessary, in mectings of naral and military oficers, to eas that no undertaling or no Institution can be conducted on proper principles unless it is on a sound and healthy system of finsuce. You cannot asccrtain whether that sgstem is sound and healthy unless you hare an intelligent and an independent audit, and therefore I venture to think that the Resolution which I hase to proposc, giring thanks to those gentle. men who gratuitously girc their scrrices to auditing the accounts of this Institution, is one of which you will uninimously approre. SIy Lord, I renturo to jroposc "That the thanks of this unceting be giren to the auditors, Lionel C. Drum. nond, Esq., E. K. Raitt, Esq., and I.ieut.-Colonel Wetherel, for their raluable serrices, and that Lionel C. Drummond, Esq., who goes out by rotation, be re. elected for the ensuing jear."

\section{Lt.-Colonel Barisis, Q.C. :-}

My Iords and Gentlemen,-It is with great pleasure that I um called upon to eccond this Resolution. We are much indebtel to the nuclitors for the great care and trouble they baro taken; but, if jou will allow we to add one xord is a member of the Finance Committec-I nerer esw accounts bettcr lept. I think wo are rery much indebted to Culonel Day for the nunoce in which thosc nceounts bitre been lept; so nccuratcly, intelligibly, and carefully, that they will bear ans inspection, and undergo any superrisicil that may be necessary. I think I an bourd to nention his name in connection with this matter.

The Resolution having been put from the Chair, was unanimously adopted.

Tho Secretary then read tho Report of tho Referees on tho Naral Essays, from which it appeared that the Gold Medal was unanimously awarded to Captain Ilenry F. Cleveland, R.N., and that the Essay by Lieutenant Bradlord, H.M.S. Muline, was recommended to be priuted in the Journal. 


\section{Geueral Sir Rolsert Hune:-}

My Lords, Ladies, and Gentlemen,-I hare tlie lionour to proposo to you the following resolution. "Tiat a rote of thithks be giren to the leferecs, Aduiral Sir George IVilles, K.C.B, Cuptain Bedford, C.13., A.I).C., K.N., and Cuptain Long, A.D.C., R.X., for their raluable services in aljudicinting on the Naral l'rizo Essas." I am surc, gentlemen, ull the wembers of this Institition nust fecl rerg grateful to the gallant officers who hare so kindly undertaken tho duty of Keferees in this unister. It is a dut.5 which, to a certuin cxtent, in:ty be called inridious and thanklezs, but I hope wo shall male up by our corlial thanks to those gallant oflicers for the was in which they hase done their work, and for the thanklessness of the rork which they have had to do.

\section{Admiral Bowdrx Surtil :-}

BIs Lord, - I lare great plcasure in seconding that Resolution.

'Tho Resolution having been put from the Chair was uuauimously adopted.

\section{Admiral Sir Grol:G: IVILLES :-}

On the part of ingsclf and niy colleagues, Captain Bedford and Captain Long, I bez to return sou our thanls for the curdial rote of the meeting. Unfortunately; l aui an idile mats, and was only too glad to be one of the Referees. I must say i should sather bave wisticel that some of the essayy were not quite so long-rrinded, but I am rery glad the Guld Jrdal has fallen to Captuin Clevcland.

\section{Adminl Sir Elelsuus Omuasisz, C.B., F.R.S.:-}

The Resolution which I hare the honour to subunit for sour approral is as follows:- "That Section I, paragraph 3 of the Bye-Iasws be altered ns follows: riz.. (3) Vice-Hatrons:-Jlembers of the Royal Family, distinguished officers, cminent persons who shall tare promoted and adranced naval and military science and literature, and others who hare beca beuefactors to the Institution, to bo selected by the Council." With segard to the honour we confer of being VicePiatrons of this Institutiou, doubtless you will perceire that those Vice-Putrons nre IIer Injesty's Ninisters and other eminent functionaries of the Gorermuent. 'The perinanent members are confined to Ficld-Mfurolials and Admirals of the Flcet. The Council hase taken this into consideration, aud with reference to tho Chister under which the Institution is iucreporated, thes are desirous to add to the representation of Vice-l'atrons, distinguisbed uen of science, and other men of eminence. I fetr of such tinen will be proposed to be selected to addl to the utmuber, and their selection, I think, will enhance the merits of the Institution out of doors, and will mect isith the approbition of the members in general. It is, I think, only following the example of many other institutions of a similar nat ure where we generally select people who aro eminent, and who hare rendered distingnished serrices to their institutions. In our Charter it is said we shall "sedulously encourage and ertend naral nud nilitars literature," and then "that it would furiher teml to the promotion and udrancement of naral and military fcicnce and literature" if the Charter were granted. I think we shall hare no dificulty in finding menbers anongst the institutions who mould be proud of this honour, and it would be onls doing our dutg in cirrging out the principles upon which this Institution was founded. I am sure there are a great nany names of norld-wide reputation and alyo national cliaracter, which, if added to this Institution, would be of rery great benefit to it. The next alteration of the B Be-Lans is in Section II, under the hesd of "Composition." The proposal is that tho following be udded :- " "5. Tenporary 


\section{xï PROCER.DINGS OE THE FIFTY-NISTI AMTVERSARY JEETING}

Members. A-l. Members of the United Serrice Institution of India proceeding to the United Fingdom on two or threa months' 'P'ririlege' learc, or on six months' Jeare, eliall bo pernitted as 'Temporary BIentbers' to attend the I.cetures and to use thie Kealing Room, Sc., of the Roynl Unitel Scrrico Institution (but not reccire the Journal) on pagntert of $n$ subscription of fire (j) shillings. 2. Should those joining as abore obtain an estension of leave, they can extend their "lem. porary IIcenbership' on the patyment of 20 additional 5s. for ang period not execcding sis months. 3. Meubers of the United Service Institution of India procceding to the Unitcd Kinglom on 'Furlough,' or leare excecding sis months, shall be permitted to attend Lectures und uso tho Rending Room, se., of tbo Royal United Serrice Institution on p2y ment of 10s. per unnunn. Should they wish nlso to receive its Journal (which can only be delirered by the Secretary on personal appliention, or to an authorised ngent, without incurring postago charges), an additional annual payment of 10s. will be necessary. 4. In the erent of 'Temporary Members, under paragriph 1, obtainiug nn extengion of leare for six muntlis, and wishing also to obtain tho Journal, they can do so nn paynent of fifteen (15) shillings in addition to the fire shillings alreads paid. 5. All the abore subscriptions to be mid in adranee, and admission as a 'Temporary J[ember' to take place on pilynient. G. The atore rulcs will npply to both Life and Annual Jiembers of the United Serrice Institution of India. B.-1. AIsmbers of the Royal United Serrice Institution sliall, throughout their scrrico in Indin, be entitled to be in all respects (including receipt of Journal without extra payment) IIembers of the United Scrice Institution of Indiz ou payment of an dunual Subscription of Rs. 5 (in adrance). C. -1. Any Jember of cither Institution will be entitled to obtain the Journal of the other on parment (in adrance) at AIembers' prices. 2. 'The Secretaries of both Institutions will interchunge lists of Members, made up to late, periodically." "The object of this resolution is to confirn an npplication cotcred into betwcen this Institution and the United Serrice Institution of India. Fou Fill casily appreciate that that rill be of rery great benefit to both Institutions. It will lead to mutual co-operntion and mutual isterehange of work. I am stire it will be of rers grcat ad rnntage to us, looking to tho distinguished officers of that great Arms in India, and to the great school for militars art und science which is afforded in the Indizn Empire.

\section{Colonel Malcoum Greex:- .}

I hare much pleasure, my Tord, in ecconding this Resolution, particularly ns the Serrices aro so intimalely connected with scienco in all its branches. I think that the permanent connection between this Institution and the Indian Institution should bo no longer delajed.

\section{Geueral Sir Beacchus Warker: :-}

As I was one of the members of the Council who opposed the introduction of the first of these two Resolutions, I hope I mas bo allowed to say a woril on the prescnt occusion. At present our Tice-l atrons nre certain nentbers of the Mlinistry, tho Viccroy of India and the Lord-Licutcnaut of Ircland, the Adeniruls of the Flect and the Ficld Marshals, and there, I think, they sloould remain. I think by the alterations proposed by Sir Erasmus Onmanney we should introduce a contentious clement. I think the addition proposed indicates a clear departure from what has been the prerious custom in respect to the Vice-l'atrons, and it would introduce a contentious elenent which we are much better mithout. One mnn will hare his pet. and another nan will hare his pet, and we sliall hare ull sorts of people put forward as Vice-Patrons, which will end in a geat deal of confusion. I therefore am most clearly of opinion that the Resolution should not be uecepted. I said so at the mecting of the Council at mhich it was considered. 'That mectinf consistcl of six Mcmbers, of whom four merc agninst me, and the other nas nifh ne. I wish that clearly to be known in this theatre, as I do not wish to pass it by with a siient rote. 


\section{Admiral Sir Finasuos OMyaxier:-}

IFith regard to the latter part of sour specch I mas say that the natter bad been disclused at a prerious meting of the Council, and u montl's notice gircn, and a notice paper eent out to erery nember of the Council.

\section{General Sir Beaduchanip W.akel: :-}

There wero but sir nembers prescut.

The Chatrmax :-

Pcrhaps I had better put theso Resolutions separately. I will first put the portion of the licsolution referring to Vice-Patrons.

Tho Resolution was put from tho Chair, and lost by a large majority.

The Cirainusas:-

I will now put the second part of the Proposal haring reference to the affiliation with the United Serrice Institution of India.

The Resolution was put from the Cliair, and was unanimously adopted.

Lorl Grosigr Inumrox then vacated the Chair, which was faken by General Ersskisr, Chairmun of the Comncil.

\section{Lord GHersisrond:-}

My Lord, Ladies, and Gentlemen, - I hare the pleasuro to propose that a roto of thints be pussed to tho Kight Honoruble Lord George Inumilton for taking the Chair upon this ocension. I should like rerg much to nidd on $\mathrm{ms}$ own aicount, and I beliere it will be the feeling of all tho:e who are present also, that the words "for lis able ronduct in the Chair" bo adled to that Resolution. We all fecl very nuch indebtel to the First Lord of the Admiralty, and to the Secretars of State for War for taling suclt a deep interest in this Institution. And when me bnow how buas those tro Oficers of the Cromn are, and bow much engaged in public affairs, it ecens to me that we cannot but pass a rery licarty vote of thants to Lord Qcorge Hamilton for haring come in this mas to help us in our Anuual Ifceting. The procecelings have lasted so much longes thin they usualls do thut I shall confine myself to this remark, being sure that all of us feel a great deal more than we are able to express to him for his kindness.

\section{Admiral Sir Gronge WiLl.Fs :-}

I hare much pleasure in cordially scconding the Resolution. Our comparatirely empty benches to-day do wot, I mm sure, imply a want of sympatliy and relcome to our noble Clatirman. 'The fact is this : a good many of us liase come to the time of life when we cannot face such weather as that of this afternoon. It is truly drctic. I linre known these dunual IIcetings in the month of MIareh to be held in warm sunshine, and then we hase teen honoured by the presenec of a number of ladies. I am sure but fur that unaroidablo cireunstance tlicy would hiare been sery glad to hare come here to-day, especially on the interesting occasion of award. ing the Gold Jredal to Captain Clcreland.

The liesolution baving been put from the Cinair, was carried by acclamation.

\section{Jon Gronge IInuluox:-}

Gcreral Erskine, ny Lords, and Gentlemen,-I thank sou for the rote lhat you baro been tind enough to pass. I think it is a good arrangement by which those nho are temporarily cntrusted with the duties of udministrntion, both of tho Army and of the Nary, shiould nlterately presile at the Annual Mectings of this most iuportant Instifution. It is two jears since last I had the honour of so doiog, and 


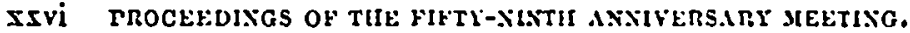

I regret to say that, in onc scnse, things aro in rery wuch the same position now ns they were then. I fear no udvance has been made as to the settlement of that all. important question of where this Institution is to bo for the future located and housed. Well, ing collcagtue, MIr. Slanliope, as well us mrself, hare done our best to impress upon the Chancellor of the Exchequer the important niture of the function which this Institution dischariges, and I think we ars fortunate, in ono oenze, in having te deal with a Chancellor of the Exchequer who himse!f was once lead of a epcuding department, in whom imperial instincts are laregels dereloped, and who has so well controlled the finances of this country, that he has giren Doro to the dring and Narg to spend than any preceliug minister, und yet has adsociatixl with that, a reduction ratluce than an incre:a?0 of tisintion. We may be sure that the Chancellor of the Exchequer will approach this question in no nigrardly opirit, but the demand put forward mas somemhat large; tho Trensurs rere asked tu erect a building to cost some $\$ 30,000$; it was to be in the close neighbourhood of Pall .Mull, which is probably the most expensire pirt of London; the rent mas to be frec; and the Institution were to be left in receipt of an income nbsolutely adequate to tincir future wants. Well, now, I do not wish to go into the disputed point that Colonel IIale lias ruised; it is quite truo that the knowledge that this Instutution ia in a dilapidated condition mas prereut its derelopment, and mas to some extentthough I do not think it ought-but may to some exicnt account for the fuct that the number of meinbers is not incresging. Hut, if JJr. Stanliope and I press the clatums of this Institution upon the Chancellor of the Exchequer, he will want us to give him some crjdence that, when that inspediment which it is said now prerents the derelopment of the Institution is renored, there is good bond fide crideuce that the Institution will largely derclop, and will plas that pirt in connection with the two Scrvices, which would alone justify that large expenditure which he is asked to iucur. Ancl, therstore, without in nny ray going into ans of tle points rhich Culunel Hale raisel, and which I am wholls incompctent to discuss, I do hope the Council will bear the "riom in anind, that if you want the Gorerunest to leclp you, jou must help jourselres as regards the future.

Now, gentlenen, it is necdless to saj that $I$ attach the highest importance to the proserration and estension of this Institution. It scems to we to discharign most important functions. So long as it is necessars, aldd 1 supposo it alwars will bo necessars under Parliamentary Guvernment, that tho alministratire head of the

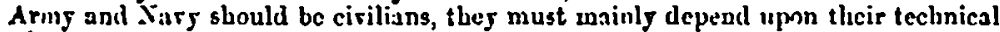
adrisers for the adrice giren in reference to the grest miss of the questions which thes lare to settle. But epenting for the Narg. I eng, no matier bow uble or industrious the Naral Lorils of tho Admiralty may be, there are a large number of questions which it is absulutely impossible for then satizfaclorily to thrash out. It scems to me, in spealing on behsalf of the Nars, that this Institution is alunost of more importunce to that Servico than to the Aring. Thero harc been great military wars during the last few jears. Those military wars hare perfectly revolutionised the systen of wilitars aduinistration. and of milit:iry tactics, and of mijitary orginisation. 'There bave been no great uaral mars. What way oceur in the next naral war is purels a matter of speculation. A great cliange, no doubr, his tiaten place in the arma unent of laud forces, but, after all, the chango is nothing coinpared to that which has taken place in tho armament of the Nars, and, therefore, it does serm to mo that this Institution ean discharge most important dutica, und especially in reference to the Nary, br discussing and elucidating part of tho problems which it is our duty to solre as fur as we can.

Trull, then, my Lords and Gevtlemen, thers is another functinn which, I think, this. Institution can satisfactorily perform. It can establish romething lite stubility and contiauity of milirary nud uarul opinion. Now I am far from saring t!at is man must not cliange his opinion, but, undoubterlly, one of the difficultics which wo hare to encounter in Parlinment is that so nasuy of the so-called experts differ on the questions on which thes are consulted. I am going to make a sugigestion. I do not know that it would be possible to make a rule that no militury or naral offecer should write a letter to a newspiaper unless be wive a momber of this Institution, and that no letter should go to the newspaper until it 
had been discussed. It ecems to mo that such a regulation might incre:sso jour numbers, and diminish the letters to the newspapers. This is a joling matter, but I can assure the naral and inilitars members hese present, that the finct that thero is rers frequently a widla difference of opinion upon such vital questions, and that differcuce expressed in the moit open way in the newejppers, by euincht military or aaval men, does gire an opportunity to those who look upon all espenditure in tho drmy and Nary as shcer waste, to oppose any propositions that are mude, because they ens that they are not zade on a firm and reliable basis, and the oflecrs are not at onc to whom they look for guidance.

Then there is another and perhaps eren more important function than cither of those which I hare inentioned, which I think this Institution can perform. I think it night do nuch torsards promoting and coneidering tho wethod br which, in certain erentualities, co-operation might be secured betwen tho tro Serrices. Tho Keport of the Commission orer which Lord IIartington has presided, will shortly be laid before the public, and will afford to all of jou most interesting reading. I know that some hare endearoured to secure co-operation betricen the tro Serricce by suzgesting that they should be under one lead, or by endearouring to apply to botls Sertices the sawe uniform regulationg, and the same conditions. In my liumble judgnent, no greater mistake can be made; cach hare their separate and distinct spleres of action; it is the luty of the Nary to prerent an attacl being made, it is the business of the Army to repel an attack when made; and if either Scrrice are allowed absolutelr to prescribe tho conditions which are applicable to tho other, thes will naturilly tale those which are the most effectire to ensble thens to disch:argo their particular scrvice, but which was be absolutely detrimental to the other Serrice tuking the duty allotted to them. In all these esentials, I belicre this Institution could do mucl. One speales spole of the legitimato intluence of authority which members of the Arms aud Nary cun csercise. I gladly bear testimony to that fact. Last year, when it wal eny businc:3 to mako centain proposals to P'urliament with referenco tu the Saral lefence of the countrs, I ras glad to fint, after a few days, that I had belind me tho absolute unaninous support of a united, logal, and powerful Serrice, and tho fact that ererg naral offecr of distinetion was prepared to sint differences of detail, in order to promoto an obje $t$ which he admitted to be good, undoubted/s greatls facilitated the pussing of that measure, and enabled $u \rightarrow$ to orercome with great cuso the only opposition which it met.

Thercfore, gentlemen, being gratcful for the assistance and support which I liave received from the Serrice with which I hare the honour to be associnted, you may rely upon ms doing erergthing in my porrer to sce that this Institution is properly locnted and properly loused. I liare nn iclea in my heul, but I cannot gire morc: it is a practicable, and I think a fe:tsible idca. I looked iuto rour finances, and I saw that although nominully jou hare a considerablo sum invested, a rery small proportion of thitt is arailable for building; I latre taken that fact into consideration. I think it was Colonel IInle who strggested thist he preferred rather that depatutions should rizit the minister, than that negotintions should be carried on by one individual. Well, now, mar I give a little warning to nll teere piesent? If there is one thing that nny officinl wan hotes, it is a deputation, und particularls a deputntion that does not nyrec, becausc we all of us work under freat presiure. We liave not rery much time to spare. I beliero if sou can get a rialls capable man in whom jou hare confidence, it is much better to entrust him with negrotiations, than to constantls bother ministers by going in large sumbers to them. There are a number of small details in connection with a clain of this sort, which require careful inrestigation, and a larpe body going befure a minister is not the kind of tribunal from which jou can clicit nceurate and minute replies to the rarious queries put. I an reminded that the hour is late, and I hare, perhape, trespissed lovger upon your time than is customars. I can onls assure you that I will do my rerg best to promote your interests, and I aus eanguine enough to hope that between now and nert yenr, we reslly shall bo on firmer ground, and that the Treasury will be in a position to male some definte aud, I Loye, acceptable offer. 